\title{
Sustainable Development in the Customs Policy and Law
}

\author{
Zrównoważony rozwój w polityce i regulacjach celnych
}

\section{Introduction}

The concept of sustainable development is currently one of the most important challenges not only for humanity, but also for various scientific disciplines. It is also a subject of the practice and theory of customs policy and customs law. At the global level, the trade - related sustainable development policy is associated with activities of the United Nations (UN) and organizations that are part of the UN system, primarily those that are related to international trade in goods: the World Trade Organization (WTO) and the World Customs Organization (WCO). The EU Customs Union is an example of regional - scale organization related to customs matters.

The aim of the article is to present the customs activities concerning sustainable development. The primary basis of the legal - institutional analysis used in the study are documents of the UN, WCO and EU, as well as reports on the implementation of the UN 2030 Agenda sustainable goals by customs services.

The main thesis of the article is that despite the auxiliary role of customs in achieving sustainable development goals, it plays a decisive role in controlling the compliance with standards related to the UN 2030 Agenda goals in the sphere of international trade in goods.

Despite the awareness of the importance of sustainable development issues, especially those associated with climate change and environmental degradation, the concept of sustainable development became a new paradigm for the activities of customs services only in the previous year, expressed in the WCO's slogan for 2020: "Customs fostering Sustainability for People, Prosperity and the Planet" (Mikuriya, 2020). The continuation of this strategy proves the WCO's official 
theme for the 2021 pandemic year: "Customs bolstering Recovery, Renewal and Resilience for a sustainable supply chain" (Mikuriya, 2021). The concept of sustainable development, regardless of the rich literature, is still disappointing because of unclear consequences for socio-economic development (Mensah, 2019). This also applies to customs, and that is why the WCO put emphasis on the promotion of knowledge and implementation into practice of the basic assumptions, values, mechanisms and instruments related to the sustainable development in the international customs environment.

The starting point for most scientific analyses are the considerations on sustainability issues contained in the report "Our Common Future", also called Brundtland report. The definition of sustainable development first appeared in this report: "Sustainable development is development that meets the needs of the present without compromising the ability of future generations to meet their own needs" (World Commission on Environment and Development [WCED], 1987, p. 41). Within this general definition, there are two opposing but equally restrictive lines of interpretation of sustainable development concept (Committee on the Environment, Agriculture and Local and Regional Affairs [CEALRA], 2003): for some it has become the basis of an excessively economic approach, often used as an excuse for increased growth which might help diminish poverty and achieve ecological balance, while at the same time fostering openness of the markets, financial deregulation, privatisation of natural resources and biopiracy. For the others, sustainable development has evolved towards oversimplified ecologism only accounting for sustainability of the natural environment. Policies, programme documents and practical activities of various institutions, organizations and countries often reflect these two extreme approaches to sustainable development.

\section{Global sustainable development framework}

The sustainable development issue - although named otherwise and focused on environmental protection - was institutionally reflected at the level of the UN organization system as early as mid-December 1972, when the special international, intergovernmental agency United Nations Environment Programme (UNEP) was established (United Nations General Assembly [UNGA], 1972). The main goal of the agency is to conduct environmental protection activities and constantly monitor environmental conditions around the world. Although, the term ,sustainable development" is not used expressis verbis, the preamble and 
the first articles of the document that specify the agency's goals, include the basic elements of this concept. As a result of its activity, the UNEP has become a natural partner for many actors of international support for the policy and practice of sustainable development.

Only a dozen years later, the concept of sustainable development was presented and broadly discussed in the Brundtland report (WCED, 1987). The report served as the basis for subsequent documents further developing the ideas of sustainability adopted at the UN Conference on Environment and Development in Rio de Janeiro in 1992 and, 10 years later, at the World Summit on Sustainable Development (WSSD) in Johannesburg - events also known as Earth Summits. Issues stemming, in fact, from the protection of the environment were the starting point of documents adopted at these conferences.

Rio Declaration on Environment and Development (United Nations Conference on Environment and Development [UNCED], 1992) introduced principles covering both the rights and obligations of countries and leading to the sustainable development of humanity while ensuring decent living conditions. The document Agenda 21 (UNCED, 1992) is a policy paper presenting the proper way to develop and implement sustainable development programmes locally. It specifies the key objectives to be achieved in the 21st century.

A follow-up to the objectives was provided by the subsequent Earth Summit held in Johannesburg in 2002, where not only the previous agreements were confirmed but also a few priorities were further specified with reference to the most immediate challenges of sustainable development (WSSD, 2002a, 2002b).

The United Nations Conference for Sustainable Development, which took place in Rio de Janeiro in June 2012, aimed to assess achievements and set up new sustainable development goals. The conference outcome document "The Future We Want" (UNGA, 2012) mandated the establishment of the platform for monitoring the progress in the sustainable development goals implementation, the so-called High Level Political Forum on Sustainable Development (HLPF). It is the main UN instrument that allows its members - both states and organizations - the annual review of the Agenda 21 goal achievements.

The next step towards sustainable development at the global level was the resolution adopted by the UN General Assembly in 2015 "Transforming our world: the 2030 Agenda for Sustainable Development", commonly known as 2030 Agenda (UNGA, 2015). The document includes 17 sustainable development goals (SDGs) and 169 targets, that address the global challenges that humanity faces and reflect the three basic dimensions of sustainable development: - economic, social and environmental. 
SDGs are briefly described as follows: 1) No Poverty, 2) Zero Hunger, 3) Good Health and Well-being, 4) Quality Education, 5) Gender Equality, 6) Clean Water and Sanitation, 7) Affordable and Clean Energy, 8) Decent Work and Economic Growth, 9) Industry, Innovation and Infrastructure, 10) Reduced Inequality, 11) Sustainable Cities and Communities, 12) Responsible Consumption and Production, 13) Climate Action, 14) Life Below Water, 15) Life on Land, 16) Peace and Justice and Strong Institutions, 17) Partnerships to achieve the Goal. All Member States of the UN have agreed to work towards achieving these objectives by the year 2030 (although some of the targets are to be achieved by 2020 or 2025).

The 2030 Agenda recognizes international trade as a driver of economic growth and poverty reduction and an important means of achieving the SDGs. Several of the targets are directly related to international trade. Task 16.4 indicates the need to combat all forms of organized crime, including a substantial reduction in the illicit arms trade by 2030. This task is extremely important today in the face of the constant threat of international terrorism and the existing tension in many regions on all continents.

Within the goal 17 there are three targets explicitly referring to international trade. Target 17.10 points out the necessity to „promote a universal, rules-based, open, non-discriminatory and equitable multilateral trading system under the WTO [...]" and target 17.12 the necessity to "realize timely implementation of duty-free, quota- free market access on a lasting basis for all least developed countries consistent with WTO decisions [...]". Target 17.11 draws special attention: "Significantly increase the exports of developing countries, in particular with a view to doubling the least developed countries' share of global exports by 2020 ". This ambitious task has not been achieved for many reasons like trade wars, the increase of various barriers on trade flows, restrictions caused by the corona virus pandemic and others. It will probably be a significant challenge for the trade of highly developed countries in the current decade of the twenty-first century.

\section{Customs and sustainable development goals}

Customs also contribute to progress in achieving SDGs. The World Customs Organization ${ }^{1}$ plays an important role in this process. It is the only internatio-

1 The World Customs Organization's formal name is the Customs Cooperation Council. The Convention establishing the Customs Cooperation Council entered into force on 4 November 1952. Since 1994 the organization has adopted its informal name "World Customs Organization", and the official name is used only when it is required by law. 
nal intergovernmental organization dealing with customs matters that brings together over 180 countries and organizations. Its direct objective is to support members in their efforts to facilitate and simplify customs procedures while ensuring the effective control of international goods supply chains. The WCO's mission involves a vision of customs in the 21st century - a broadly understood group of social relationships related to international trade in goods - under the slogan: "Bringing Customs together for a safer and more prosperous world. Borders divide, Customs connects" (WCO, n. d.). This idea serves also as the basis for goals resulting from the concept of sustainable development.

The role and importance of customs in meeting the challenges of the current century, including those related to sustainable development, was reflected in the WCO strategic document entitled "Customs in the 21st Century" (WCO, 2008). Although, the wording "sustainable development" is not mentioned, the document describes the role of customs administrations in the socio-economic development of communities. This role is not limited to the international trade in goods controls and to facilitation and simplifications of customs procedures. It also encompasses tasks associated with the safety of international trade flows, the protection of fauna and flora and the environment, the safety and health of people. Tasks that have been formulated in this document are consistent - to a large degree - with the 2021 Agenda goals and then also to the 2030 Agenda goals.

Functions performed by customs play key roles in achieving SDGs [compare also the pictogram scheme (WCO, 2018)]. Among others, the most important are the control, fiscal, protective, trade facilitation, export promotion and educational functions.

The fiscal function, export promotion and trade facilitation function performed by customs administrations contribute to the achievement of SDG 1 "End poverty in all its forms everywhere". The fiscal function of customs is the oldest and best known one. It is still important, although its role is decreasing as a result of simplification and facilitation of trade processes and the development of various forms of economic integration - agreements on free trade areas or customs unions. Nevertheless, in many cases, revenues from customs duties and other levies collected by a country's customs service serve to meet the budgetary needs. This applies especially to developing countries and countries with dominant mono-cultural economies or inadequate other budget revenues. Therefore, customs participates in country's socio-economic development and hence in reducing poverty.

Trade facilitation and export promotion functions are associated with business friendly customs procedures, such as: economic or suspensive procedures, 
principally the lack of tariff and non-tariff barriers in exports, facilitating and simplifying import procedures for goods from underdeveloped and developing countries to get access to high developed markets and many others. They stimulate a socio-economic development, an increase in fair competition, growth of budget revenues from taxes on production and services, as well individual income taxes etc. As a result, the budget revenues can be fairly redistributed - in democratic countries - for the common welfare, for improvement of the health care system and the educational system, building of infrastructure, etc. In the least developed and developing countries, the export promotion function enables the increased production of goods that have easier, fair access to the markets of developed countries.

The cooperation with other border control authorities such as Police, Border Guard etc. and customs services of other countries positively affects the realization of SDG 2 "End hunger, achieve food security and improved nutrition and promote sustainable agriculture", SDG 3 "Ensure healthy lives and promote wellbeing for all at all ages", SDG 7 "Ensure access to affordable, reliable, sustainable and modern energy for all" and SDG 13 "Take urgent action to combat climate change and its impacts". Such cooperation ensures trading remains consistent with health and environment protection regulations and maintains fast, safe and efficient supply chains for food products, water, beverages and medical and sanitary products.

Educational function of customs plays a key role in the realization of SDG 4 "Ensure inclusive and equitable quality education and promote lifelong learning opportunities for all". This goal is approached from two perspectives: the perspective of customs staff and the perspective of international trade stakeholders. All customs staff must be well informed and well trained, among others, in the area of sustainable development issues: e-learning and educational platforms ease the access to knowledge. Most of the information that various stakeholders require to do their jobs is published on the WCO website and national customs websites, so it is easily accessible.

Trade facilitation function of customs supports the achievement of SDG 5 "Achieve gender equality and empower all women and girls" and SDG 10 "Reduce inequality within and among countries". By facilitating trade, customs contribute to development of small-scale trade and job opportunities creation for marginalized communities, reducing gender, ethnic and other inequalities. Customs administrations permanently work on simplifying and standardizing border procedures and create transparent and foreseeable conditions for trade. This facilitates the legitimate business development that, in turn, positively 
influences economic growth and job opportunities. So, the business facilitation function of customs contributes, in an obvious way, to the achievement of SDG 8 "Promote sustained, inclusive and sustainable economic growth, full and productive employment and decent work for all".

The implementation of SDG 9 „Build resilient infrastructure, promote inclusive and sustainable industrialization and foster innovation" is aided by customs procedures enabling the timely delivery of raw materials for industry, supporting innovation and protection of intellectual property rights and through the collection of customs and tax duties. All this supports the development of infrastructure, especially in developing countries.

The control and protective functions play important roles in achieving of the SDGs 11, 12, 14 and 15.

Customs is responsible for the control of international trade in goods compliance with applicable import/export laws and regulations. The control function includes the control on: duties to be paid, description of goods in customs declarations, goods origin and value, security and safety measures, compliance with environmental, veterinary, phytosanitary and quality regulations, etc. The protective function of customs services includes not only tariff protections but also non-tariff forms of protection against trade in dangerous goods, harmful for human beings, animals and environment. This function is also related to the protection of fair competition and the fight against smuggling and other crimes resulting from non-compliance with the customs law. Modern methods of custom clearance and non-invasive, innovative methods of customs control - risk analyses, post audit, etc. - accelerate the fair turnover of goods and thus capital turnover, strengthening the budget system. Finally, the protection against illicit trade in all kinds of weapons and uncontrolled trade in endangered species of wild flora and fauna is extremely important. Profits from such illegal trade can be a source of international terrorism financing.

Customs administrations support the achievement of SDG 11 "Make cities and human settlements inclusive, safe, resilient and sustainable”. They facilitate legal international trade in goods, fight effectively against fraud and smuggling and thereby against unfair competition, protecting local communities from harm.

Customs services are responsible for border clearance of goods, including consumer goods. They play a key role in the elimination and prevention of trade in counterfeit goods and goods that are dangerous to the life, health and safety of consumers and influence the way of producing and consuming goods and resources. Hence, they contribute to achieving SDG 12 "Responsible Consumption and Production". 
Customs administrations have a key role to play in achieving of SDG 14 "Conserve and sustainably use the oceans, seas and marine resources for sustainable development" and SDG 15 "Protect, restore and promote sustainable use of terrestrial ecosystems, sustainably manage forests, combat desertification, and halt and reverse land degradation and halt biodiversity loss". Implementation of these goals covers a wide range of activities including monitoring, detection and prevention of international environmental crime such as illegal trade in endangered species of flora and fauna, illegal logging and trade in timber species and trade in ozone depleting substances.

By complying with the customs law, fighting against border crime and by preventing the smuggling of prohibited and dangerous goods, customs services provide access to justice for international trade stakeholders and contribute to the achievement of SDG 16 "Promote peaceful and inclusive societies for sustainable development, provide access to justice for all and build effective, accountable and inclusive institutions at all levels".

The role of customs in achieving of SDG 17 "Strengthen the means of implementation and revitalize the global partnership for sustainable development" is quite apparent, as customs regularly cooperates - at the national and international levels - with both public and private entities, on the basis of multilateral or bilateral trade related agreements.

The use of international conventions and WCO's instructions, guidelines, and recommendations that are constantly updated to reflect the latest changes in law and practice, significantly supports customs services in the implementation process of sustainable development goals.

\section{Examples of WCO's practice initiatives}

The WCO has implemented several specific programmes and conducted a number of special operations to combat customs crime related to non-compliance with customs laws and procedures supporting sustainable development.

In 2008, the WCO adopted a Recommendation Concerning Actions Against Cross-Border Environmental Offences (Customs Co-operation Council, 2008). The document encourages customs authorities to organize and participate in joint operations against environmental crimes. To provide coordinated support for combating wildlife crimes, the WCO with other four international organizations, namely the CITES Secretariat (CITES - Convention on International Trade in Endangered Species of Wild Fauna and Flora), INTERPOL, the United Nations 
Office on Drugs and Crime and the World Bank, established the International Consortium on Combating Wildlife Crime in 2010.

In the frame of the Environmental Programme launched two years later, WCO is constantly working on expanding the scope of partnerships with other organizations in the field of combating environmental crime. In recent years, the WCO has signed memoranda of understanding with the CITES Secretariat, the Basel Convention Secretariat, the United Nations Environment Programme, the Lusaka Agreement Task Force and Trade Records Analysis of Flora and Fauna in Commerce (TRAFFIC) - a non-governmental organization working on trade in wild flora and fauna in the context of sustainable development and biodiversity preservation.

In June 2014, the WCO adopted the Declaration on the Illegal Wildlife Trade (Customs Co-operation Council, 2014). Its goal was to involve customs and business in the timely, consistent and globally coordinated response to wildlife crimes.

Customs also plays a crucial role in enforcing the requirements of Multilateral Environmental Agreements (MEAs) concluded by the international community to combat environmental crimes. The WCO is an active partner of the Green Customs Initiative (UNEP, 2004), a partnership of international organisations cooperating to prevent the illegal trade in environmentally-sensitive commodities. Conducted activities are coordinated by the United Nations Environment Programme. One of the aims of the Green Customs Initiative is to raise the awareness and knowledge of customs officials on trade related MEAs.

The first joint global operation named "Operation DEMETER" (WCO, 2009) targeted to combat illegal transboundary movements of dangerous and other waste, was conducted in 2009. This operation was unprecedented in scale and scope. A total of 65 customs administrations participated in it. Customs officers intensified the risk assessment and profiling at more than 300 seaports and other selected locations and carried out more than 2000 physical controls in order to identify high risk shipments. Participating customs administrations were supported by their national environmental agencies, police forces, the Secretariat of the Basel Convention, the EU Network for Implementation and Enforcement of Environmental Law, and the seven WCO Regional Intelligence Liaison Offices. The total seizures for Operation DEMETER amount to 86 cases with almost 46 thousands of tons of seized waste. The operation was repeated in the following years. The last (6th) version of the operation DEMETER was launched in 2020.

Operation COBRA is an example of a large-scale cross-border operation to combat crime against illegal trade in wild animals protected by the CITES 
Convention. It was performed by customs, police and wildlife officers from Asia, Africa and the United States, in 2013. Operation COBRA yielded hundreds of arrests and resulted in the seizure of assorted wildlife specimens, such as Tibetan antelope wool, red sander wood, elephant ivory, live snakes, hornbill beaks etc. (WCO, 2013). Similar operations, known as COBRA II and COBRA III were carried out in the next two years and resulted in thousands of seizures of protected species and led to the arrest of hundreds of suspects.

WCO launched the INAMA project in 2014. The project was designed to strengthen the enforcement capacity of customs administrations in Sub-Saharan Africa and to prevent the illegal trade in wildlife, particularly on species listed in the appendices of CITES (WCO, 2015). The third edition of the programme, INAMA III, was kicked off in September 2019 and will continue until September 2021.

\section{Sustainable Development in EU Customs Law}

The concept of sustainable development takes an important place in the EU legislation. The Amsterdam Treaty amending the Treaty on the European Union, signed in 1997, introduced sustainable development as a core principle and objective of the European Union. Provisions on sustainable development have been included in the following primary law documents: the Treaty on the European Union (TEU), the Treaty on the Functioning of the European Union (TFEU) and the Charter of Fundamental Rights of the European Union (CFREU). The Preamble to the TEU states that the signatories are determined to promote economic and social progress for their peoples, taking into account the principle of sustainable development and within the context of the accomplishment of the internal market and of reinforced cohesion and environmental protection, and to implement policies ensuring that advances in economic integration are accompanied by parallel progress in other fields. Article 3(3) of the TEU states, among other things, that the internal market shall work for the sustainable development of Europe based on balanced economic growth and price stability, a highly competitive social market economy, aiming at full employment and social progress, and a high level of protection and improvement of the quality of the environment. The TEU also points out the role of the EU in relation to the sustainable development of the Earth (TEU, art. 3(5), art. 21(2f) and developing countries, with the primary aim of eradicating poverty (TEU, art. 21(d). Policy integration is underlined in the TFUE (art.11). Article 11 says that environmental protection requirements must be integrated into the definition and 
implementation of the Union's policies and activities, in particular with a view to promoting sustainable development. The concept of sustainable development occurs also in the CFREU (Preamble and art. 37). Article 37 provides a high level of environmental protection and the improvement of the quality of the environment must be integrated into the policies of the Union and ensured in accordance with the principle of sustainable development.

It is worth to notice that the above-mentioned provisions cannot be regarded as offering a legal definition. Sustainable development is expressed as an objective or a principle. According to some authors, a legal definition in EU primary law is not necessary as the arrangements arising from international documents on sustainable development should be used. However, in each case when interpreting the meaning of this expression, the point of reference must be fundamental values of the UE set out in art. 2 of TEU (Syryt \& Klimska, 2019).

Both lawyers and scientists worldwide deal with the legal status of sustainable development and its potential legal consequences under international, EU and national laws. Just as examples we can mention a few works. Brown (1995) argues that sustainable development is not a norm of the international law. Decleris (2000) in his report produced for the European Commission presents a comprehensive approach to the sustainable development law, including proposals of legal definitions of sustainable development from different perspectives. Sander in the preface to this report assures that the Treaty of Amsterdam has sufficiently explained the legal status of sustainable development and that it is a fundamental principle for the EU Member States who have also shared the EU's experience in this scope. Peeters and Schomerus (2016) answer the question whether references to sustainable development in binding law have any significant consequences for legal practice. Kenig-Witkowska (2017) analyses the concept of sustainable development in the EU policy and law and Syryt \& Klimska (2019) investigate the problem of ethical and legal conditions of sustainable development from the perspective of EU primary law.

Secondary EU legal acts must not contradict the primary law provisions, including those related to the sustainable development. This also applies to the EU customs law.

A direct reference to the concept of sustainable development is not to be found even in the extended package of EU customs regulations comprising the Union Customs Code (UCC), Delegated Acts, Implementing Regulations, the Transitional Delegated Acts and the Action Programme. Norms of the package refer directly only to one of its dimension - fundamental but not exclusive - i.e. to the natural environment protection issues. Already in Article 3 of the Union 
Customs Code (European Parliament and Council, 2013) the legislator states that customs authorities are aimed, among others, to provide security and safety for the European Union and its residents, as well as the protection of the natural environment. Goods brought into the customs territory of the Union, are subject to customs supervision (UCC, art. 134). The legislator points out the necessity of prohibitions and restrictions resulting, among others, from requirements of the protection of the health and life of humans, animals or plants, the natural environment and the national cultural assets as well as fishery conservation. A similar principle of restrictions and prohibitions applies to goods to be taken out of the customs territory of the Union (UCC, art. 267).

Application of customs law norms also supports economic and social aspects of the sustainable development concept. The supervision of the international exchange of goods is exercised primarily by customs authorities who thereby contribute to fair and open trade, implementation of external aspects of the internal market, the common trade policy and the other common Union policies referring to the commercial turnover and the safety of the whole supply chain (UCC, art. 3).

Hence, the requirement of sustainability of development, including the need for the natural environment protection, has found - directly or indirectly - its place among the main goals of the EU customs regulations. Such an approach requires balancing of economic, social and nature conservation considerations. It also requires accounting for political factors to contradict the contemporary paradox: the fact that despite the general support of the principle of sustainable development we tend to adopt a short-term perspective to our daily issues and apply quantitative measures to essentially material phenomena (CEALRA, 2003).

One of the EU's recent initiatives (European Parliament, 2021) in the field of climate protection is to impose a carbon border levy (customs duty or import tax) on products with high carbon footprints. This would apply to certain goods (like cement, steel, aluminium, chemicals, fertilizers etc.) from countries with less strict carbon emission rules. The import of such products to the EU is de facto the import of carbon emission resulting from the process of their production. This initiative aims to achieve a higher level of climate goals in the EU and create an incentive for the EU and non-EU trade industries to cut carbon emissions. The European Commission is expected to present the legislative proposal on a carbon border adjustment mechanism in July 2021 and a full implementation is planned for 2026 .

Besides EU law, there are other important instruments of international law that need to be taken into account by EU Member States' customs administrations. International conventions referring to sustainable development or rather, to be 
more precise, to the protection of climate and the natural environment, directly oblige customs services to the control of the turnover of goods. As examples we might mention here the Convention on International Trade in Endangered Species of Wild Fauna and Flora (CITES), the Stockholm Convention on Persistent Organic Pollutants, the Rotterdam Convention on the Prior Informed Consent Procedure for Certain Hazardous Chemicals and Pesticides in International Trade, the Basel Convention on the Control of Transboundary Movements of Hazardous Wastes and their Disposal, the Montreal Protocol on Substances that Diversity, and the Convention Concerning the Protection of the World Cultural and Natural Heritage.

The most efficient norms turn out to be the ones which result from check procedures related to enforcement of the customs law (in its widest meaning). This concerns both enforcement of restrictions and prohibitions in the turnover of specific goods related to the protection of sustainable development, and a preference for fair trade in goods originating from the lowest developed and developing countries. In a broader perspective this refers to the Generalised System of Preferences and Economic Partnership Agreements or Free Trade Agreements aimed to advance the social and economic development of these countries through customs easings aiding accessibility of their products on the markets of highly developed countries.

However, the endeavours made by lawyers aimed to solve the problem of sustainable development on the international level with the use of traditional legal instruments, especially international agreements, have proven insufficient (CEALRA, 2003). This is also largely true nowadays. In a world that has become a global village, worldwide problems must be seen in terms of interdependence. Close international cooperation among states is needed to find solutions.

Brown (1995) pointed out that many developed countries support the natural environment protection while developing countries give a priority to issues related to development. They oppose having the protection imposed on them and they prefer to avoid international agreements seen as limiting their national sovereignty. Due to the threat to the national sovereignty states do not agree to the limits on the exploitation of natural resources on their territory. Additionally, a set of international and national regulations on the natural environment protection is often internally incohesive and it only fragmentarily provides for the protection. This is still in general true today. Unless the developed nations become much more effective in helping the developing nations economically or through the transfer of technology, the developing nations are unlikely to make progress on the path toward sustainable development. 


\section{Conclusions}

The discussed UN, WCO and EU documents, mechanisms, instruments and actions play important roles in custom's contribution to achieving SDGs outlined in the United Nations' 2030 Agenda.

Customs contributes to the realisation of the SDGs mainly through efficient performing of its functions and responsibilities and through increasing effectiveness in the implementation of standards contained in the international conventions referring to sustainability matters, especially environmental and climate protection. Moreover, customs services - in cooperation with other control services - participate in large-scale cross-border operations-to combat customs crime related to non-compliance with customs laws.

However, in the customs policy and regulations - which obviously have only a subsidiary role as regards economic and social policies - sustainable development is still being seen mainly from the perspective of financial purposes and has been oversimplified in its ecological dimension, largely limited to the natural environment protection and containing the climate change. This approach is considerably risky as it does not contribute to balancing economic, social and environmental concerns. Due to political actions, in the future this may result in "latency" of the support for the principle of sustainable development, seen most broadly - also from the social perspective related to the needs of the future generations and nations of the least developed countries, as they are going to strive for a decent life.

Sustainable development remains one of the most important challenges for the customs services in the modern world. The role of customs in implementation of SDGs has increased during the coronavirus pandemic crisis. The WCO Annual Report 2019-2020 points out that:

The crisis showed that seizures of counterfeit products, protected species, wildlife, etc., can play a role in protecting people and the planet. Customs could raise awareness through extended communication at this level and launch discussions at governmental level to be more efficient at the borders. The penalties for offenders could be made more severe in order to significantly change behaviours in the future. Again, more controls on the internet and stricter frameworks for informal trade could impact the flows of endangered species and dissuade smugglers.

Sustainable development is also a challenge for the sciences related to the theory of customs policy and law. It is necessary to develop better, more effective 
control methods, while accelerating and facilitating a secure international supply chain and customs clearance of goods.

\section{Acknowledgment}

The authors thank Dr. Viera Gafrikova for her significant contribution to the preparation of this article.

\section{References}

\section{Normative acts}

Charter of Fundamental Rights of the European Union (CFREU). (2012, 26 October). Official Journal of the European Union C 326/391. Retrieved from https://eur-lex.europa. eu/legal-content/EN/TXT/PDF/?uri=CELEX:12012P/TXT\&from=HR (15.02.2021).

European Parliament and Council (2013, 10 October). Regulation (EU no 952/2013 of the European Parliament and the Council laying down the Union Customs Code (recast), Official Journal of the European Union L 269. Retrieved from https://eur-lex.europa.eu/legal-content/EN/TXT/PDF/?uri=CELEX:32013R0952\&from $=\mathrm{EN}(11.02 .2021)$.

Treaty of the European Union - consolidated version (2012, 26 October). Official Journal of the European Union C 326/13. Retrieved from https://eur-lex.europa.eu/ resource.html?uri=cellar:2bf140bf-a3f8-4ab2-b506-fd71826e6da6.0023.02/ DOC_1\&format=PDF (10.03.2021).

Treaty on the Functioning of the European Union - consolidated version (2012, 26 October). Official Journal of the European Union C 326/47. Retrieved from https://eur-lex.europa.eu/legal-content/EN/TXT/PDF/?uri=CELEX:12012E/ TXT\&from $=\mathrm{EN}(10.03 .2021)$.

\section{Literature}

Brown, D.A. (1995). The Role of Law in Sustainable Development and Environmental Protection Decisionmaking. In: J. Lemons., D.A. Brown (Eds.), Sustainable Development: Science, Ethics, and Public Policy (pp. 64-76). Dordrecht: Springer. doi: 10.1007/978-94-015-8492-0_5

Commission of the European Communities (2001). A Sustainable Europe for a Better World: A European Union Strategy for Sustainable Development. Retrieved from https://eur-lex.europa.eu/legal-content/EN/TXT/PDF/?uri=CELEX:52001DC0264\&from $=\mathrm{EN}(13.01 .2021)$. 
Commission of the European Communities (2005). Draft declaration on guiding principles for sustainable development. Retrieved from https://eur-lex.europa. eu/LexUriServ/LexUriServ.do?uri=COM:2005:0218:FIN:EN:PDF (13.01.2021).

Committee on the Environment, Agriculture and Local and Regional Affairs (2003). Globalisation and sustainable development. Report. https://assembly.coe.int/ nw/xml/XRef/X2H-Xref-ViewHTML.asp?FileID=9961 (30.07.2021).

Customs Co-operation Council (2008). Recommendation of the Customs Co-Operation Council Concerning Actions against Cross-Border Environmental Offences. Retrieved from http://www.wcoomd.org/-/media/wco/public/global/ pdf/about-us/legal-instruments/recommendations/enforcement/cross_borderenvironmantal-offences.pdf?la=en (30.03.2021).

Customs Co-operation Council (2014). Declaration of the Customs Co-Operation Council on the Illegal Wildlife Trade. Retrieved from http://www.wcoomd. org/en/about-us/legal-instruments/ /media/BC96FE063BF848AD83E3ADB56B0A79BE.ashx (21.03.2021).

Decleris, M. (2000). The law of Sustainable Development General Principles. A Report Produced for the European Commission. Retrieved from https://www. pik-potsdam.de/avec/peyresq2003/talks/0917/sillence/background_literature/ sustlaw.pdf (15.02.2021).

European Commission (2019). Reflection paper. Towards a Sustainable Europe by 2030. Retrieved from https://ec.europa.eu/info/sites/info/files/rp_sustainable_europe_30-01_en_web.pdf (20.03.2021).

European Parliament (2021). MEPs set to call for carbon levy on EU imports to raise global climate ambition, Newsletter 8-11 March 2021, Plenary Session, p. 10. Retrieved from https://www.europarl.europa.eu/pdfs/news/expert/2021/3/briefing/20210222BRI98343/20210222BRI98343_en.pdf(30.05.2021).

Kenig-Witkowska, M. (2017). The Concept of Sustainable Development in the European Union Policy and Law. Journal of Comparative Law and Policy, 1(1), 64-80. Retrieved from https://readingroom.law.gsu.edu/cgi/viewcontent. cgi? article $=1005 \&$ context $=$ jculp (05.01.2021).

Mensah, J. (2019). Sustainable development: Meaning, history, principles, pillars, and implications for human action. Literature review. Cogent Social Sciences, 5(1). Retrieved from https://www.tandfonline.com/doi/full/10.1080/23311886.2019.1 653531 (05.01.2021).

Mikuriya, K. (2020). WCO celebrates International Customs Day 2020 and invites Members to foster Sustainability for People, Prosperity and the Planet. Retrieved from http://www.wcoomd.org/en/media/newsroom/2020/january/ international-customs-day-2020.aspx (18.03.2021). 
Mikuriya, K. (2021). Message from the World Customs Organization. International Customs Day 2021. Retrieved from http://www.wcoomd.org/-/media/wco/ public/global/pdf/about-us/international-customs-day/2021/icd_2021_messagefrom-the-wco-secretary-general_en.pdf?db=web (18.03.2021).

Peeters, M., Schomerus, T. (2016). Sustainable Development and Law, 109-118. In: H. Heinrichs, P. Martens, G. Michelsen, A. Wiek (Eds.), Sustainability Science. Dordrecht: Springer. doi: 10.1007/978-94-017-7242-6_9

Syryt, A., Klimska, A. (2019). Ethical and Legal Conditions - the Perspective of Primary EU Law and the Case Law of the Court of Justice of the European Union in Matters of Environmental Protection. Scientific Papers of the Silesian University of Technology. Organisation and Management, Series No. 137. Retrieved from https://www.polsl.pl/Wydzialy/ROZ/ZN/Documents/Zeszyt\%20137/Syryt,\%20 Klimska.pdf (10.02.2021).

The International Consortium on Combating Wildlife Crime (2010). What is ICCWC? Retrieved from https://cites.org/eng/prog/iccwc_new.php (30.03.2021).

United Nations Conference on Environment and Development (1992). Agenda 21. Retrieved from https://sustainabledevelopment.un.org/outcomedocuments/ agenda21 (30.04.2021).

United Nations Conference on Environment and Development (1992). Rio Declaration on Environment and Development. Retrieved from https://www.un.org/en/ development/desa/population/migration/generalassembly/docs/globalcompact/A_CONF.151_26_Vol.I_Declaration.pdf (10.12.2020).

United Nations Environment Program (2004). The Green Customs Initiative. Retrieved from https://www.unenvironment.org/explore-topics/environmental-governance/ what-we-do/strengthening-institutions/green-customs (30.03.2021).

United Nations Framework Convention on Climate Change (2015). Adoption of the Paris Agreement. $21^{\text {st }}$ session Conference of the Parties. Paris. Retrieved from https:// unfccc.int/resource/docs/2015/cop21/eng/109r01.pdf (10.01.2021).

United Nations General Assembly (1972). Resolutions adopted on the reports of the Second Committee 2997 (XXVII). Institutional and financial arrangements for international environmental cooperation. Retrieved from http://www. worldlii.org/int/other/UNGA/1972/85.pdf (10.01.2021).

United Nations General Assembly (2012). Resolution adopted by the General Assembly on 27 July 2012, 66/288 The future we want. Retrieved from https://www. un.org/ga/search/view_doc.asp?symbol=A/RES/66/288\&Lang=E (10.12.2020).

United Nations General Assembly (2015). Resolution adopted by the General Assembly on 25 September 2015, 70/1. Transforming our world: the 2030 Agenda for 
Sustainable Development. Retrieved from https:/www.un.org/ga/search/ view_doc.asp?symbol=A/RES/70/1\&Lang=E (25.02.2021).

World Commission on Environment and Development (1987). Report. Our common future. Retrieved from https://sustainabledevelopment.un.org/content/documents/5987our-common-future.pdf (15.12.2020).

World Customs Organization (n.d.). Vision, Mission and Values, http://www.wcoomd. org/en/about-us/what-is-the-wco/vision-mission-values.aspx (25.02.2021).

World Customs Organization (2008). Customs in the 21st Century. Enhancing Growth and Development through Trade Facilitation and Border Security. Annex II to Doc. SC0090Ela. Retrieved from http://www.wcoomd.org/-/media/wco/ public/global/pdf/topics/key-issues/customs-in-the-21st-century/annexes/annex_ii_en.pdf?la=en (30.03.2021).

World Customs Organization (2009). Operation DEMETER. Executive Summary. Retrieved from http://www.wcoomd.org/-/media/wco/public/global/pdf/topics/ enforcement-and-compliance/activities-and-programmes/environmental-crime/ ex_sum_demeter_en.pdf (13.03.2021).

World Customs Organization (2013). Asia and Africa join hands to crack down on wildlife crime syndicates. Press Release. Retrieved from http://www.wcoomd.org/en/ media/newsroom/2013/february/asia-and-africa-join-hands.aspx (13.03.2021).

World Customs Organisation (2015). Project INAMA: enhancing Sub-Saharan. Customs' capacity to fight illegal wildlife trade. WCO news. $\mathrm{N}^{\circ} 78$ October 2015. Retrieved from http://www.wcoomd.org/ /media/wco/public/global/pdf/ topics/capacity-building/activities-and-programmes/cooperation-programme/ wco-news-october-2015-inama-en2.pdf?db=web (15.12.2020).

World Customs Organization (2018). The role of the customs in achieving the SDGs. Retrieved from http://www.wcoomd.org/-/media/wco/public/global/pdf/about-us/wco-in-brief/sdgs2018.pdf?db=web (24.03.2021).

WCO Annual Report 2019-2020, p. 37. Retrieved from http://www.wcoomd.org/-/me$\mathrm{dia} / \mathrm{wco} /$ public/global/pdf/about-us/annual-reports/annual-report-2019_2020. $\operatorname{pdf}(30.07 .2021)$.

World Summit on Sustainable Development (2002a). Johannesburg Declaration on Sustainable Development. Retrieved from http://www.un-documents.net/ jburgdec.htm (15.12.2020).

World Summit on Sustainable Development (2002b). Plan of Implementation of the World Summit on Sustainable Development. Retrieved from http://www. un-documents.net/jburgpln.htm (15.12.2020). 


\section{Summary}

The article describes the contribution of customs to the implementation of sustainable development goals included in the UN 2030 Agenda. The paper presents the historical outline of the sustainable development concept and explains how basic tasks performed by customs contribute to the achievement of these goals. World Customs Organization plays an important role in activities for sustainable development, especially its numerous political and practical initiatives, including international operations of customs services aimed at combating environmental crime. The article analyzes also the EU customs regulations and activities of the EU Member States' customs services. The decisive role of customs in controlling the compliance with the sustainable development requirements related to international trade in goods as well as a need for wider cooperation with other control services and business is emphasized.

KeYwords: Sustainable development, customs legislation, UN 2030 Agenda, World Customs Organization, EU customs law.

\section{Streszczenie}

W artykule omówiono wkład celnictwa w realizację celów zrównoważonego rozwoju zawartych w dokumencie ONZ Agenda 2030. Przedstawiono zarys historyczny koncepcji zrównoważonego rozwoju oraz pokazano, w jaki sposób celnictwo, pełniąc swoje podstawowe funkcje, przyczynia się do osiągania tych celów. W działaniach na rzecz zrównoważonego rozwoju ważną rolę odgrywa Światowa Organizacja Celna, w szczególności jej liczne polityczne i praktyczne inicjatywy, w tym międzynarodowe operacje służb celnych, mające na celu zwalczanie przestępstw przeciwko środowisku. Analizie poddano także unijne regulacje celne i działalność służb celnych państw członkowskich UE. Podkreślono decydującą rolę celnictwa w kontroli przestrzegania wymogów zrównoważonego rozwoju w międzynarodowych obrotach towarowych oraz konieczność szerszej niż dotychczas współpracy z innymi służbami kontrolnymi i biznesem.

SŁOWA KLUCzowE: zrównoważony rozwój, ustawodawstwo celne, Agenda ONZ 2030, Światowa Organizacja Celna, prawo celne UE.

\section{Noty o autorach}

Wiesław Czyżowicz - prof. dr hab., Szkoła Główna Handlowa, Kolegium Nauk o Przedsiębiorstwie; główne obszary działalności naukowej: polityka i prawo celne, międzynarodowa, unijna i polska, historia celnictwa, międzynarodowe stosunki gospodarcze i polityczne; e-mail: wesczyz@sgh.waw.pl; ORCID: 0000-0002-3147-8280.

Ewa Gwardzińska - dr hab., prof. SGH, Szkoła Główna Handlowa, Kolegium Nauk o Przedsiębiorstwie; główne obszary działalności naukowej: prawo celne, przedstawicielstwo celne, polityka celna, międzynarodowy obrót towarowy; e-mail: egwardz@sgh.waw.pl; ORCID: 0000-0003-1656-2078. 
